\title{
Cellulose-negative Mutants of Acetobacter xylinum
}

\author{
BySVEIN VALLA AND JOHS. KJOSBAKKEN* \\ Department of Biochemistry, The Norwegian Institute of Technology, N-7034 Trondheim- \\ NTH, Norway
}

(Received 9 September 1981)

\begin{abstract}
Cellulose-negative mutants of Acetobacter xylinum have been isolated. Chemical mutagenesis induced a high frequency of such mutants without significant cell killing. Cellulose synthesis could be activated phenotypically in the majority of the mutants by antibiotics that block RNA or protein synthesis. Therefore these mutations are not in the structural genes coding for the enzymes involved in cellulose synthesis, but their nature is not known. All of the spontaneous cellulose-negative mutants and the mutants induced by ethyl methanesulphonate or nitrous acid reverted when grown statically, but about $10 \%$ of the nitrosoguanidineinduced mutants did not.

Growth experiments with mixed cultures of the wild-type and cellulose-negative mutants were used to analyse the biological function of cellulose in A. xylinum. The celluloseproducing wild-type has a strong selective advantage compared with the cellulose-negative mutants when grown statically. This is in agreement with the hypothesis (Schramm \& Hestrin, 1954) that cellulose enables the cells to reach the surface of the liquid medium, where the supply of oxygen is abundant. Cellulose-negative mutants may be enriched in shake flask cultures because of selective aggregation of cellulose-producing cells.
\end{abstract}

\section{INTRODUCTION}

Cellulose is the most abundant organic polymer in nature, where it plays a crucial role in the integrity of plant cell walls (Colvin, 1980; Preston, 1979; Shafizadeh \& McGinnis, 1971). In spite of the importance of cellulose, the mechanism of its biosynthesis is still poorly understood (Colvin, 1980; Delmer, 1977; Shafizadeh \& McGinnis, 1971). Acetobacter xylinum synthesizes a cellulose which is very similar to plant cellulose, and this bacterium has therefore been used extensively as a model organism in studies on cellulose formation (Colvin, 1980; Zaar, 1977).

Recently we have started to analyse cellulose biosynthesis in A. xylinum by genetical techniques (Valla \& Kjosbakken, 1981). We here describe the isolation and characterization of cellulose-negative mutants formed spontaneously as described by Schramm \& Hestrin (1954), and produced after treatment of the cells with various mutagens. We propose to designate the genes involved in cellulose formation by the symbol cel, and the celluloseproducing wild-type and the cellulose-negative phenotypes will be named $\mathrm{Cel}^{+} \mathrm{or}^{-\mathrm{Cel}^{-}}$. It has been proposed that cellulose has an important function in static cultures of A. xylinum, enabling the cells to reach the air/liquid interface where the supply of oxygen is abundant (Schramm \& Hestrin, 1954). With $\mathrm{Cel}^{-}$mutants it is possible to study this problem, and the results are presented in this paper.

\section{METHODS}

Buffers. TM buffer (Adelberg et al., 1965) is a Tris/maleate buffer; the phosphate/citrate buffer has been described by Hestrin \& Schramm (1954). 
Growth of cells. Cells of Acetobacter xylinum (ATCC 10245) were grown under static or shaking conditions, as indicated, at $30^{\circ} \mathrm{C}$. Unless otherwise stated, incubations were performed with $25 \mathrm{ml}$ of the medium described by Hestrin \& Schramm (1954) in 250 ml flasks.

Harvesting of cells. Cultures were homogenized with an Ultra-Turrax TP 18-10 homogenizer, and cells were freed from cellulose as described by Hestrin \& Schramm (1954). For mutagenesis and estimation of the spontaneous mutation frequencies, only cells from the cellulose pellicle were used. The pellicles were washed three times in TM buffer prior to homogenization.

For mutagenesis the undiluted cellulose-free cell suspension described above was sedimented, and the cells were resuspended in $100 \mathrm{ml}$ prewarmed medium followed by incubation at $30^{\circ} \mathrm{C}$ with shaking for $2 \mathrm{~h}$. The aggregates formed were homogenized and cellulose was removed as described above. After centrifugation the cells were washed once in TM buffer and resuspended to a cell concentration of $2 \times 10^{8}$ cells $\mathrm{ml}^{-1}$ in different buffers, depending on the mutagen used.

Conditions of mutagenesis and identification of $\mathrm{Cel}^{-}$mutants. Mutagenesis with $N$-methyl- $N^{\prime}$-nitro- $N$ nitrosoguanidine (NG) $\left(10 \mu \mathrm{g} \mathrm{ml}^{-1}\right)$ and ethyl methanesulphonate (EMS) $\left(25 \mu \mathrm{ml}^{-1}\right)$ was performed in TM buffer for $30 \mathrm{~min}$. Mutagenesis with hydroxylamine was done in $0.15 \mathrm{M}$-hydroxylamine, $\mathrm{pH} 6.0$, for $70 \mathrm{~min}$. Treatment with nitrous acid was done in $0.1 \mathrm{M}$-acetate buffer, $\mathrm{pH} 4 \cdot 6$, containing $50 \mathrm{~mm}-\mathrm{NaNO}_{2}$; the incubation time was $15 \mathrm{~min}$. All incubations were done in test tubes containing $2 \mathrm{ml}$ of the cell suspensions, with shaking at $30^{\circ} \mathrm{C}$. Ultraviolet (u.v.) mutagenesis was done with $10 \mathrm{ml}$ cell suspension in $0.1 \mathrm{M}-\mathrm{MgSO}_{4}$. The suspension was kept in a glass Petri dish ( $9 \mathrm{~cm}$ diam.) on a slowly tilting table. U.v. irradiation $(254 \mathrm{~nm})$ was for 2 min at $15 \mathrm{~cm}$ distance with a CAMAG TL 900 u.v. lamp.

The cell suspensions were washed once in TM buffer to remove the mutagens, serially diluted, and plated on the medium described by Hestrin \& Schramm (1954). The u.v.-treated cells were diluted without washing and plated in dim light, and the plates were incubated in the dark. All plates were incubated at $30^{\circ} \mathrm{C}$. The numbers of $\mathrm{Cel}^{+}$and $\mathrm{Cel}^{-}$colonies developing on the plates were scored by visual inspection. The validity of this method for identification was always checked by using the staining method of Passmore \& Carr (1975) with $25 \mu \mathrm{g}$ Tinopal UP $\mathrm{ml}^{-1}$ (Ciba-Geigy) added to the medium.

Controls were included in all experiments. These were treated exactly like the mutagenized cells, but with the omission of the mutagen. About $10^{4}$ colonies from each control experiment were inspected, and no $\mathrm{Cel}^{-}$mutants were found.

Tetracycline induction of cellulose synthesis. Cells were grown with shaking in a 21 Erlenmeyer flask containing $400 \mathrm{ml}$ medium to a cell density of $2 \times 10^{8}$ cells $\mathrm{ml}^{-1}$ (time zero). Samples $(15 \mathrm{ml})$ of the exponential phase culture were transferred to a series of $100 \mathrm{ml}$ Erlenmeyer flasks containing tetracycline to give a final concentration of 25 $\mu \mathrm{g} \mathrm{ml}{ }^{-1}$. All flasks were incubated at $30^{\circ} \mathrm{C}$ with shaking. Controls without tetracycline were treated exactly as described above.

Measurement of cellulose synthesis. Incubations were stopped and cellulose was isolated as described by Dennis \& Colvin (1965). Quantitative determination of cellulose was performed according to Dearing (1957).

Measurement of synthesis of the soluble extracellular polysaccharide. Growth of cells and tetracycline treatment were done as described above for induction of cellulose synthesis. Since there was no aggregate formation in this particular experiment, it was not necessary to have separate flasks for each sample during treatment with tetracycline. At various times after addition of tetracycline, $5 \mathrm{ml} \mathrm{samples}$ were withdrawn, and cells were removed by centrifugation and filtration (Valla \& Kjosbakken, 1981). The polysaccharide was precipitated from $2 \mathrm{ml}$ filtrate by adding $10 \mathrm{ml} 95 \%$ cold ethanol. After centrifugation at $7500 \mathrm{~g}$ for $10 \mathrm{~min}$, the sediment was resuspended in $2 \mathrm{ml} 50 \mathrm{~mm}-\mathrm{NaCl}$, and the polysaccharide reprecipitated with ethanol as described above. The resuspension and precipitation was repeated, and the polysaccharide was finally dissolved in $2 \mathrm{ml}$ water. Neutral carbohydrates were measured by the anthrone reaction (Scott \& Melvin, 1953).

\section{RESULTS}

\section{Isolation of $\mathrm{Cel}^{-}$mutants}

Schramm \& Hestrin (1954) found that spontaneously formed Cel- mutants of $A$. xylinum would accumulate if the wild-type was grown and transferred repeatedly in shake flask cultures. We have obtained 50 independent $\mathrm{Cel}^{-}$mutants with this method. Surprisingly, all these mutants reverted to pellicle-forming, cellulose-producing strains when grown statically. Such cultures contained mixtures of cells forming mucoid colonies, indistinguishable from the original inoculum $\left(\mathrm{Cel}^{-}\right)$, and cells forming colonies morphologically identical to the cellulose-producing wild type $\left(\mathrm{Cel}^{+}\right)$. The cellulose-producing strains were most abundant in 
Table 1. Formation of cellulose-negative mutants after treatment of A.xylinum wild type with various mutagens

\begin{tabular}{lcc}
\multicolumn{1}{c}{ Mutagen } & Survival & $\begin{array}{c}\text { Frequency of } \\
\text { cellulose-negative } \\
\text { mutants }\end{array}$ \\
Nitrosoguanidine & $8.6 \times 10^{-1}$ & $3 \times 10^{-2}$ \\
Ethyl methanesulphonate & $8.3 \times 10^{-1}$ & $5 \times 10^{-3}$ \\
Nitrous acid & $1.0 \times 10^{-3}$ & $2 \times 10^{-3}$ \\
Hydroxylamine & $7.9 \times 10^{-3}$ & $<10^{-4}$ \\
U.v. light & $4.5 \times 10^{-3}$ & $<10^{-4}$
\end{tabular}

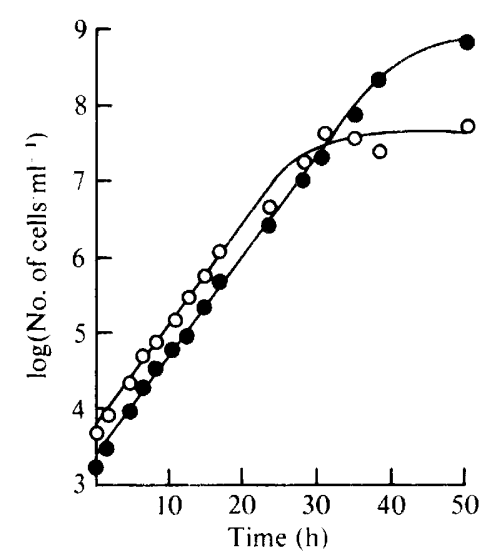

Fig. 1. Growth kinetics of a mixed culture of a $\mathrm{Cel}^{+}$(wild type) and a $\mathrm{Cel}^{-}$strain of $A . x y l i n u m$ in shaken culture. The spontaneous $\mathrm{Cel}^{-}$mutant used was isolated as described at the beginning of Results. At appropriate times during growth, $0.05 \mathrm{ml}$ samples were removed from the liquid phase, without homogenization of aggregates. After dilution, viable counts of the two strains were determined by plating on agar medium. $\mathrm{O}, \mathrm{Cel}^{+}$(wild type); $\mathrm{O}, \mathrm{Cel}^{-}$.

all cultures, but the ratio between $\mathrm{Cel}^{+}$and $\mathrm{Cel}^{-}$colonies varied considerably. These data are in agreement with the results obtained recently by Cook \& Colvin (1980).

The shake flask method for mutant selection favours the isolation of strains which grow as fast or faster than the wild type. It cannot be excluded that this procedure selects a certain class of $\mathrm{Cel}^{-}$mutants. We decided, therefore, to use various mutagens for the isolation of $\mathrm{Cel}^{-}$ mutants from $A$. xylinum. As can be seen from Table 1, NG and EMS induced a high frequency of $\mathrm{Cel}^{-}$mutants, even though the survival was very high. Nitrous acid was also active, while no mutants could be observed after treatment with hydroxylamine or after u.v. irradiation. The majority of the independently isolated $\mathrm{Cel}^{-}$mutants reverted when grown statically. However, about $10 \%$ of the NG-induced mutants did not revert under static conditions.

\section{The biological function of cellulose in A. xylinum}

The reason why spontaneous $\mathrm{Cel}^{-}$mutants accumulate after repeated transfers in shake flask cultures became clear from the experiment described in Fig. 1. At low cell densities both the $\mathrm{Cel}^{+}$wild type and the $\mathrm{Cel}^{-}$mutant grew exponentially, with identical generation times of about $2 \mathrm{~h}$. At a cell density of about $10^{7}$ cells $\mathrm{ml}^{-1}$, aggregates became visible, and the number of wild-type cells in the dispersed phase did not increase further, while the number of $\mathrm{Cel}^{-}$ cells continued to increase. The most obvious explanation for this phenomenon is that aggregates are formed selectively by the $\mathrm{Cel}^{+}$wild type while the $\mathrm{Cel}^{-}$mutants continue their dispersed growth. This assumption was confirmed by washing followed by homogenization 


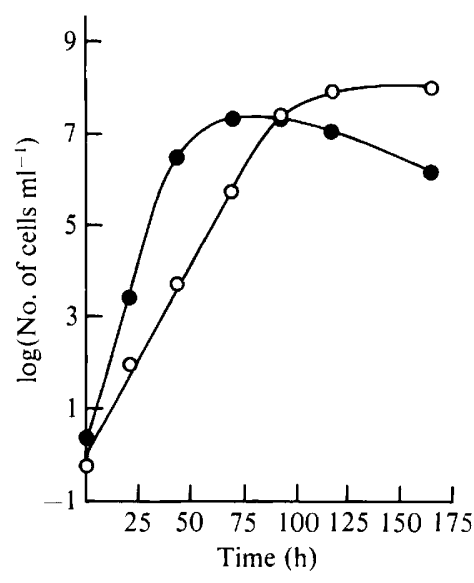

Fig. 2

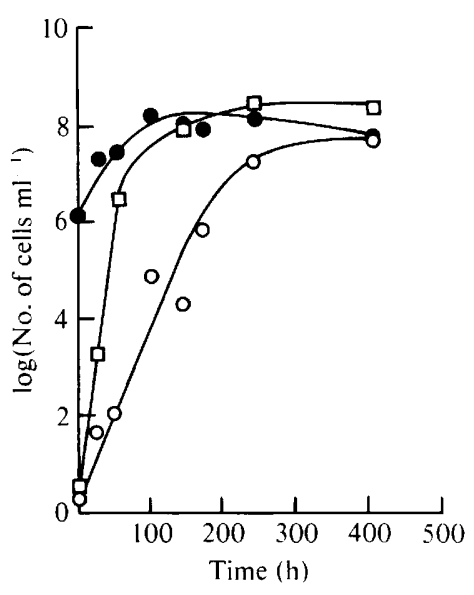

Fig. 3

Fig. 2. Growth kinetics of a mixed culture of a $\mathrm{Cel}^{+} \mathrm{Nal}^{\mathrm{r}}$ and a $\mathrm{Cel}^{-} \mathrm{Nal}^{\mathrm{s}}$ strain of $A$. xylinum in static culture, with a low initial $\mathrm{Cel}^{-} / \mathrm{Cel}^{+}$ratio. Each point represents one culture flask. Cells were grown statically in $250 \mathrm{ml}$ flasks containing $100 \mathrm{ml}$ medium, and the cultures were homogenized before determination of viable counts. Cells were plated on agar medium with nalidixic acid $\left(50 \mu \mathrm{g} \mathrm{ml}^{-1}\right)$ for determination of the number of wild-type cells, and without antibiotic for determination of the number of mutant cells. The mutant used in the experiment, Cel71, was a non-reverting NG-induced mutant. $\mathrm{O}, \mathrm{Cel}^{+} \mathrm{Nal}^{+} ; \mathrm{O}, \mathrm{Cel} 71\left(\mathrm{Cel}^{-} \mathrm{Nal}^{\mathrm{s}}\right)$.

Fig. 3. Growth kinetics of a mixed culture of a $\mathrm{Cel}^{+} \mathrm{Nal}^{r}$ and a $\mathrm{Cel}^{-} \mathrm{Nal}^{\mathrm{s}}$ strain of $A$. xylinum in static culture, with a high initial $\mathrm{Cel}^{-} / \mathrm{Cel}^{+}$ratio. The experiment was done as described in the legend to Fig. 2 , except for the different ratio between the two strains in the inoculum. $\square, \mathrm{Cel}^{+} \mathrm{Nal}^{\mathrm{r}}$ alone; $\mathrm{O}, \mathrm{Cel}^{+} \mathrm{Nal}^{\mathrm{r}}$ in mixed culture;, $\mathrm{Cel} 71\left(\mathrm{Cel}^{-} \mathrm{Nal}^{\mathrm{s}}\right)$ in mixed culture.

and plating of the aggregates. The apparent selection of $\mathrm{Cel}^{-}$mutants by growth in shake flask culture is thus at least partly a consequence of the method of sampling, the $\mathrm{Cel}^{-}$cells being transferred and the $\mathrm{Cel}^{+}$cells in the aggregates being left behind. We have not measured the growth rate of the cells in the aggregates, but it seems reasonable to believe that aggregate formation may lead to prolonged generation times.

The isolation of non-reverting $\mathrm{Cel}^{-}$mutants by NG mutagenesis made it possible to estimate any possible selective advantage of cellulose production in a static culture. For these experiments we also isolated a spontaneous nalidixic acid-resistant derivative of the wild type. By plating cells on agar medium containing nalidixic acid we were able to detect small numbers of the wild type in mixtures with a large excess of $\mathrm{Cel}^{-}$mutants, and to follow the growth of the wild type in mixed culture. The results of an experiment where the initial ratio of $\mathrm{Cel}^{-}$to $\mathrm{Cel}^{+}$cells was three are shown in Fig. 2. The mixture was incubated statically. Initially, the mutant grew faster than the wild type, and the ratio between the two types was 1000 after $2 \mathrm{~d}$ incubation. At a cell density of about $10^{7}$ cells $\mathrm{ml}^{-1}$ the mutant stopped growing, while the wild type continued to grow, and eventually dominated the culture after $4 \mathrm{~d}$. The results of a similar growth experiment, in which the initial mutant/wild type ratio $\left(10^{6}\right)$ was strongly in favour of the mutant, are shown in Fig. 3. Again the wild type continued to grow after the growth of the mutant had stopped, and finally the numbers of the two types were the same. In this case the wild type grew much faster in the absence of the mutant, while growth of the mutant was unaffected by the presence of the wild type.

\section{Analysis of the spontaneous mutation frequency in cellulose synthesis}

Shimwell (1956) and Shimwell \& Carr (1964) have suggested that mutations occur extremely frequently in the genus Acetobacter, while Schell \& De Ley (1962) argued against this conclusion. We believe that none of these authors distinguished clearly enough between 


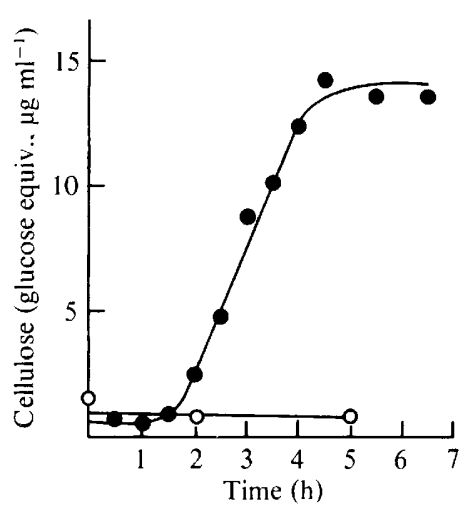

Fig. 4

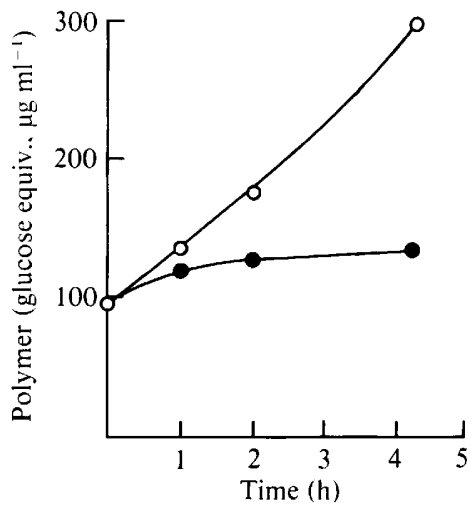

Fig. 5

Fig. 4. Induction of cellulose synthesis in a $\mathrm{Cel}^{-}$mutant by tetracycline. The mutant used in this experiment, Cel 1, was the one used previously for the isolation of a soluble extracellular polysaccharide (Valla \& Kjosbakken, 1981). Tetracycline was added at time zero. O, Incubation without tetracycline; , incubation with tetracycline.

Fig. 5. Effect of tetracycline on synthesis of a soluble extracellular polysaccharide. The $\mathrm{Cel}^{-}$strain used in this experiment, Cel67, was a non-reverting, non-inducible NG mutant. Tetracycline was added at time zero. $O$, Incubation without tetracycline; $\mathbf{O}$, incubation with tetracycline.

mutant frequency and mutation frequency. From our experiments on the biological function of cellulose in $A$. xylinum, it is obvious that such a distinction may be very important for the analysis. By growing the cells with shaking at low cell densities, the problem of selection of mutants due to aggregation of the wild-type cells was eliminated (see Fig. 1). From such experiments we conclude that the spontaneous frequency of mutation in cellulose biosynthesis is lower than $10^{-5}$ mutations per cell per generation. The very high frequency of cellulosenegative mutants often observed during routine cultivation of the wild-type $A$. xylinum is thus due to biological selection and not to an extremely high mutation frequency.

\section{Induction of cellulose synthesis in $\mathrm{Cel}^{-}$mutants}

During our studies on the properties of the spontaneous $\mathrm{Cel}^{-}$mutants, we discovered that many of them formed aggregates similar to the $\mathrm{Cel}^{+}$wild type when cells from old cultures were resuspended in fresh medium, or when cells were grown under nitrogen limitation. In a search for a more defined way of inducing aggregate formation, we discovered that addition of tetracycline to exponentially growing cells resulted in extensive aggregate formation. Preliminary characterization showed that the cells in the aggregates were separated by treatment with cellulase. The kinetics of cellulose production in the absence and presence of tetracycline was measured for one of these strains (Fig. 4). There was a strong induction of cellulose synthesis about $90 \mathrm{~min}$ after the addition of tetracycline, followed by a linear accumulation for about $3 \mathrm{~h}$. Similar results could be obtained with chloramphenicol or rifamycin, instead of tetracycline. Induced cells from Cel1 and from two other inducible strains (Cel2 and Cel4) were plated. In all cases, the colonies were mucoid and indistinguishable from the original $\mathrm{Cel}^{-}$mutants. The colonies were also inoculated for growth in shake flasks, and none of them produced cellulose aggregates. These data show that the tetracycline induction is phenotypic, and is, therefore, different from the genotypic reversion which occurs when most of the $\mathrm{Cel}^{-}$mutants are grown statically.

Induction of cellulose formation by tetracycline is common also among the $\mathrm{Cel}^{-}$mutants isolated by mutagenesis. In general, we have found that more than $50 \%$ of the cellulose-negative strains are inducible. The amount of cellulose produced after induction varies considerably between strains. 
Table 2. Relation between loss of ability to synthesize cellulose and degree of resistance to ampicillin

Cultures were inoculated from wild-type colonies. Cells were harvested and plated on agar medium containing $15 \mu \mathrm{g}$ ampicillin $\mathrm{ml}^{-1}$. The frequency of $\mathrm{Cel}^{-}$mutants in the absence of ampicillin was less than $10^{-3}$ in all suspensions.

$\begin{array}{ccc}\begin{array}{c}\text { Suspension } \\ \text { no. }\end{array} & \text { Survival } & \begin{array}{c}\text { Frequency of } \\ \text { cellulose-negative } \\ \text { mutants among } \\ \text { survivors }\end{array} \\ 1 & 3.0 \times 10^{-4} & 6.4 \times 10^{-3} \\ 2 & 5.6 \times 10^{-5} & 2.3 \times 10^{-1} \\ 3 & 8.0 \times 10^{-5} & 2.4 \times 10^{-1} \\ 4 & 1.5 \times 10^{-4} & 1.1 \times 10^{-1} \\ 5 & 5.5 \times 10^{-5} & <10^{-3}\end{array}$

We have reported recently that an $A$. xylinum $\mathrm{Cel}^{-}$mutant (Cel1) can synthesize large amounts of an extracellular soluble polysaccharide different from cellulose, and we suggested that there might be some indirect connection between the biosynthesis of cellulose and the soluble polysaccharide (Valla \& Kjosbakken, 1981). We have now found that several of our $\mathrm{Cel}^{-}$mutants produce this soluble polysaccharide. The effect of tetracycline is not restricted to the stimulation of cellulose synthesis: the synthesis of the other polymer is inhibited about $30 \mathrm{~min}$ after the addition of tetracycline (Fig. 5). Addition of tetracycline to inducible strains therefore results in a switch from the synthesis of a soluble extracellular polysaccharide to cellulose. The mechanism of this switch is not known at present.

\section{A possible pleiotropic effect on cellulose formation}

We believe that the most reasonable explanation for the properties of the mutants is that the cells can become $\mathrm{Cel}^{-}$either by mutations in the structural genes for cellulose biosynthesis or by mutations in other genes which are indirectly involved in the formation of this polysaccharide. The exact nature of the genes giving such a pleiotropic effect is, however, difficult to identify. The enzymes participating in the formation of the cellulose microfibril seem to be cell envelope bound, and the polyglucosan chains are extruded through the envelope into the extracellular environment (Brown, 1981). Mutations in several genes determining the structure of the cell envelope might, therefore, interfere indirectly with cellulose formation. The results shown in Table 2 are in agreement with this hypothesis. Wild-type cells were plated on agar medium containing ampicillin at concentrations which would kill most of the cells. Among the surviving cells there was a much higher frequency of $\mathrm{Cel}^{-}$mutants than in the total cell population. Since ampicillin inhibits cell wall synthesis, the survivors are probably cell envelope mutants. This hypothesis is also supported by the observation that mutations in the genes coding for the outer membrane proteins of Escherichia coli have been shown to interfere with polysaccharide biosynthesis (Gayda et al., 1979).

\section{DIS CUSSION}

Chemical mutagenesis of $A$. xylinum wild type induces a high frequency of $\mathrm{Cel}^{-}$mutants. This effect is especially strong with NG as mutagen. Since the survival was high (approx. $86 \%$ with NG), and the cells were not grown between mutagenesis and scoring for the $\mathrm{Cel}^{+} / \mathrm{Cel}^{-}$property, the high frequency of mutants must be caused by the mutagen directly. The results can be explained in at least two fundamentally different ways: the genes involved in cellulose biosynthesis may be hit more easily than other genes, or cellulose biosynthesis is influenced by genes other than the structural genes for cellulose formation. We believe that the 
latter explanation is the more probable, since most of the $\mathrm{Cel}^{-}$mutants can synthesize cellulose under certain conditions, for instance, after inhibition of protein synthesis. Such an effect would not be expected if the structural genes for cellulose biosynthesis had been mutated. The exact nature of these mutations has not been identified, but it is interesting to note that activation of cellulose synthesis is accompanied by a block in the synthesis of another extracellular polysaccharide. Perhaps the mutants are unable to synthesize cellulose and the soluble polysaccharide at the same time. This is, however, not the case for the wild type, since these cells can synthesize both polysaccharides simultaneously in shaking cultures.

Mutations in cellulose biosynthesis also give rise to pleiotropic effects, as exemplified by the increased ampicillin resistance. Such effects have also been observed during activation of colanic acid synthesis in $E$. coli, where activated cells were often more u.v. sensitive, more tetracycline resistant, derepressed in the gal operon, or inhibited in cell division (Markovitz, 1977). One class of these mutants (capR) seems to be mutated in a gene coding for a protein with both DNA-binding and proteolytic activity (Zehnbauer et al., 1981). Interestingly, we have observed that many of our $\mathrm{Cel}^{-}$mutants do not grow on defined medium (Colvin et al., 1977) or require higher concentrations of yeast extract. Some also grow extremely slowly and in filaments. The results obtained from work on colanic acid synthesis may therefore be highly relevant for the study of cellulose formation in A. xylinum.

Using some of the $\mathrm{Cel}^{-}$mutants, we have investigated the biological function of cellulose in A. xylinum, and have shown that $\mathrm{Cel}^{-}$mutants accumulate in shake flasks partly because of selective sampling on transferring cells from one culture to the next. Since wild-type cells grow exponentially at low cell densities, the cells do not form any aggregates under these conditions. Evidently either a certain minimum cell density and cellulose concentration is necessary for aggregate formation to occur, or cellulose is not produced before a certain cell density is reached. Electron microscopy of carbon replicas of the wild-type cells harvested in the exponential phase showed the presence of large amounts of cellulose microfibrils, suggesting that the first hypothesis is correct. Analysis of static cultures showed that initially the $\mathrm{Cel}^{-}$ mutants grow faster than the wild type. The growth of the mutant stops at an earlier stage than the growth of the wild type. We believe that these results can most easily be explained by two factors: aggregate formation and oxygen limitation. In static culture the wild type forms small aggregates, which presumably results in prolonged generation time. At higher cell densities oxygen becomes limiting, and only those cells that are near the surface of the culture medium (the cellulose producers) obtain a sufficient oxygen supply. The establishment of the cellulose pellicle may also function as a filter blocking the oxygen diffusion into the culture medium.

The strong selective pressure in favour of the wild type in static culture also explains why most $\mathrm{Cel}^{-}$mutants revert under these conditions. This pressure is so strong that it is not necessary to postulate an unusually high frequency of reversion in order to explain the observed results.

This work was supported by grants from Anders Jahre's fond til vitenskapens fremme and from the Norwegian Research Council for Science and Humanities.

\section{REFERENCES}

Adelberg, E. A., Mandel, M. \& Chen, G. C. C. (1965). Optimal conditions for mutagenesis by $N$-methyl- $N^{\prime}$-nitro- $N$-nitrosoguanidine in Escherichia coli K12. Biochemical and Biophysical Research Communications 18, 788-795.

Brown, R. M., JR (1981). Integration of biochemical and visual approaches to the study of cellulose biosynthesis and degradation. In International Symposium on Wood and Pulping Chemistry, vol. 3,
Biosynthesis and Biodegradation of Wood Components, pp. 3-15. Stockholm.

Colvin, J. R. (1980). The biosynthesis of cellulose. In Biochemistry of Plants, vol. 3, Carbohydrates: Structure and Function, pp. 543-570. Edited by J. Preiss. New York: Academic Press.

Colvin, J. R., ChĖnè, L., Sowden, L. C. \& Takal, M. (1977). Purification and properties of a soluble polymer of glucose from cultures of Acetobacter 
xylinum. Canadian Journal of Biochemistry $\mathbf{5 5}$, 1057-1063.

Cook, K. E. \& Colvin, J. R. (1980). Evidence for a beneficial influence of cellulose production on growth of Acetobacter xylinum in liquid medium. Current Microbiology 3, 203-205.

DeARING, G. G. (1957). Micromethod for the estimation of cellulose. Nature, London 179, 579.

Delmer, D. P. (1977). The biosynthesis of cellulose and other plant cell wall polysaccharides. Recent Advances in Phytochemistry 11,45-77.

Dennis, D. T. \& Colvin, J. R. (1965). The relation between cellulose biosynthesis and the structure of the cell envelope in Acetobacter xylinum. In Cellular Ultrastructure of Woody Plants, pp. 199-212. Edited by W. A. Côte, Jr. Syracuse, New York: Syracuse University Press.

Gayda, R. C., Avni, H., Berg, P. E. \& Markovitz, A. (1979). Outer membrane protein a and other polypeptides regulate capsular polysaccharide synthesis in E. coli K12. Molecular and General Genetics 175, 325-332.

Hestrin, S. \& SChramM, M. (1954). Synthesis of cellulose by Acetobacter xylinum. 2. Preparation of freeze-dried cells capable of polymerizing glucose to cellulose. Biochemical Journal 58, 345-352.

MARKovitz, A. (1977). Genetics and regulation of bacterial capsular polysaccharide biosynthesis and radiation sensitivity. In Surface Carbohydrates of Procaryotic Cells, pp. 415-462. Edited by I. Sutherland. New York: Academic Press.

Passmore, S. M. \& CARR, J. G. (1975). The ecology of the acetic acid bacteria with particular reference to cider manufacture. Journal of Applied Bacterio$\log y$ 38, 151-158.

Preston, R. D. (1979). Polysaccharide conformation and cell wall function. Annual Review of Plant Physiology 30, 55-78.

Schell, J. \& DE LEY, J. (1962). Variability of acetic acid bacteria. Antonie van Leeuwenhoek 28, 445465.

SChramm, M. \& Hestrin, S. (1954). Factors affecting production of cellulose at the air/liquid interface of a culture of Acetobacter xylinum. Journal of General Microbiology 11, 123-129.

Scort, T. A. \& Melvin, E. H. (1953). Determination of dextran with anthrone. Analytical Chemistry 25, 1656-1661.

Shafizadeh, F. \& McGinnis, G. D. (1971). Morphology and biogenesis of cellulose and plant cell walls. Advances in Carbohydrate Chemistry and Biochemistry 26, 297-349.

SHIMwELL, J. L. (1956). Transmutation of species in the genus Acetobacter. Journal of the Institute of Brewing 62, 339-343.

Shimwell, J. L. \& CARR, J. G. (1964). Mutant frequency in Acetobacter. Nature, London 201, $1051-1052$.

VALLA, S. \& KJOSBAKKEN, J. (1981). Isolation and characterization of a new extracellular polysaccharide from a cellulose-negative strain of Acetobacter xylinum. Canadian Journal of Microbiology 27, 599-603.

ZAAR, K. (1977). Biogenesis of cellulose by Acetobacter xylinum. Cytobiologie 16, 1-16.

Zehnbauer, B. A., Foley, E. C., Henderson, G. W. \& Markovitz. A. (1981). Identification and purification of the $\operatorname{Lon}^{+}\left(c a p \mathrm{R}^{+}\right)$gene product, a DNA-binding protein. Proceedings of the National Academy of Sciences of the United States of America 78, 2043-2047. 